\title{
LEMMEX — an agile approach to service design consultancies
}

Helouíse Hellen de Godoi Viola

PhD student, Universidade Federal de Santa Catarina / helo.hellen@gmail.com $\underline{\text { lattes }}$

Israel de Alcântara Braglia

PhD, Universidade Federal de Santa Catarina / israelbraglia@gmail.com $\underline{\text { lattes }}$ 


\title{
LEMMEX - an agile approach to service design consultancies
}

\begin{abstract}
This article deals with the application of an agile approach to projects in design service used in consultancies of the LEMMEUFSC group in partnership with Sebrae-SC. The methodological procedure used for the case study (LEMMEX) adapts an adaptation of the flowchart of Teixeira, Henrique, Braglia \& Gonçalves (2018); developed from the approaches of Garret (2010) and Teixeira, Benedet and Hoppe (2015). The standardized method of optimization in the analysis time, greater depth in the relevant items for the proposed solution and more security for decision making.
\end{abstract}

Keywords: design service. agile methodologies. user experience. 


\title{
LEMMEX - uma abordagem ágil para consultorias em service design
}

\begin{abstract}
RESUMO
O presente artigo trata sobre a aplicação de uma abordagem ágil para projetos em design service utilizadas em consultorias do grupo LEMME - UFSC em parceria com o Sebrae/SC. Foram selecionados três casos aqui descritos. O procedimento metodológico utilizado para o estudo de caso (LEMMEX) propõe uma adaptação do fluxograma de Teixeira, Henrique, Braglia \& Gonçalves (2018); desenvolvido a partir das abordagens de Garret (2010) e de Teixeira, Benedet e Hoppe (2015). O método empregado permitiu otimização no tempo de análise, maior profundidade nos itens relevantes para proposta de solução e mais segurança para tomada de decisões.
\end{abstract}

Palavras-chave: design service. metodologias ágeis. user experience. 


\title{
LEMMEX - un enfoque ágil para las consultorías de diseño de servicios
}

\begin{abstract}
RESUMEN
Este artículo trata sobre la aplicación de un enfoque ágil a proyectos en servicio de diseño utilizados en consultorías del grupo LEMME - UFSC en alianza con Sebrae/SC. El procedimiento metodológico utilizado para el estudio de caso (LEMMEX) és una adaptación del diagrama de flujo de Teixeira, Henrique, Braglia \& Gonçalves (2018); desarrollado a partir de los enfoques de Garret (2010) y Teixeira, Benedet y Hoppe (2015). El método de optimización en el tiempo de análisis, mayor profundidad en los ítems relevantes para la solución propuesta y más seguridad para la toma de decisiones.
\end{abstract}

Palabras clave: design service. Metodologías ágiles. user experience. 


\section{INTRODUCTION}

In the design context, due to the expansion of digital communication, the importance of developing systematic methods and approaches focusing on the user experience (UX) is seen in order to obtain improvements in sales activities. The user's involvement in the experience on all "fronts" of digital communication is essential for the success of the product or service. Based on this premise, the LEMME Group carried out, in partnership with Sebrae-SC, consultancies in design service with a focus on digital communication in clothing and footwear retail stores, based on an agile approach, continuous innovation, product adaptability, audience and processes, better time to market and reliable results (HIGHSMITH, 2009).

\section{AGILE PROJECTS, USER EXPERIENCE AND SALES}

\subsection{Agile}

The agile approach is characterized by its adaptability, that is, by its power to deal with changes brought about by the market, by requirements of systems and products, implementation technologies or in project teams (COOCKBRUN, 2002).

Therefore, its development combines a creative work team with a focus on effectiveness and maneuverability (HIGHSMITH; COCKBURN, 2001) due to its structure will favor continuous learning of the needs of end users, allowing small advances and rapid improvements, both in the product and in analysis development process and decision making.

According to Highsmith (2009) the agile approach aims at continuous innovation (for deliveries within the current requirements of customers), product adaptability (to deliver 
within the future requirements of the customer), people and processes (to respond quickly to product changes and business), improved time to market (to meet market windows to improve return on investment) and reliable results (to support business growth and profitability). Agile development recognizes that there are uncertainties and possibilities for error involved in the proposed solutions, and works on these uncertainties by performing systematic tests of these solutions (DAWSON; DAWSON, 1998; PERMINOVA; GUSTAFSSON; WIKSTROM, 2008; STEFFENS; MASTINSUO; ARTTO, 2007). Therefore, it seeks to mitigate these uncertainties through successive prototypes and tests at different times of maturity of the project to verify what happens and, consequently, learn and innovate from these experiments and from user feedback.

\subsection{User-centered Design}

Digital communication has advanced, gained strength and great power for handling and sales (in the context related to restrictions due to Covid-19 it has been strongly evidenced the value of its expansion and reach). Therefore, it should be done in a resolute, objective and assertive manner. For this it is necessary to have a focus on the human being. The communication of products and services must consider the new vision of Marketing 4.0: its social essence, according to Kotler, Kartajaya, Setiwan (2017). In this scenario that the User Experience comes into play, it is important to place the user at the center of the projects taking into account their experience, as this, the more successful it will enable greater repercussion of communication in the digital environment and, consequently, sales. 
Interdisciplinarity and multidisciplinarity have contributed to advances in this regard. In other words, the perspectives coming from cognitive science, administration, software engineering, design, among others, have strengthened a set of elements that communicate in order to obtain a better experience in the use of products by their respective users.

Therefore, the focus is no longer on the product itself, but on its use, or on the experience that the user of the given product will have. According to Dewey (2010) experience is the foundation of interaction with the environment, "it means an active and alert exchange with the world; at its peak, it means a complete interpretation between the self and the world of objects and events" (DEWEY, 2010, p. 83). In the design area, through the research of Donald Norman (1986; 2004; 2006), the terms User Experience (UX) and User Centered Design (User-Centered Design) has gained notoriety. For the author, there are mental models with which the human mind works, therefore, knowing such models facilitates communication between design and the user, so his research qualifies that the focus should be on knowing the human being, centering all the process in him and in his interaction with the world.

Based on these premises, Garrett (2010), with the incorporation of a greater emphasis on visual design, develops an interaction design framework considering three dimensions of the user experience: aesthetic, emotional and functional. Such a framework is structured in five plans: strategic, scope, structure, skeleton and surface, explained below:

Strategic Plan: aims to identify what is wanted with the development of the interface and what the user needs.

Scope Plan: assists in transforming the strategic plan into requirements, which are broken down into resources for 
the interface. This plan lists functions and content related to the interface.

Sckeleton Plan (Hierarchy): at this moment the functions and contents are presented according to a hierarchy that is established according to the user's characteristics, aptitudes, preferences and needs.

Structure Plan (Wireframes): step that makes the prototyping of the interface possible. For this, the hierarchy established in the Structural Plan must be respected.

Surface Plan: in this plan, what has been produced so far is joined and transformed into screens that will serve as a basis for the development and implementation team.

Thus, it is clear that the most abstract plan is related to the strategy, while the most concrete plan is directed to the details of the interface presentation.

Figure 1: Experience Plan

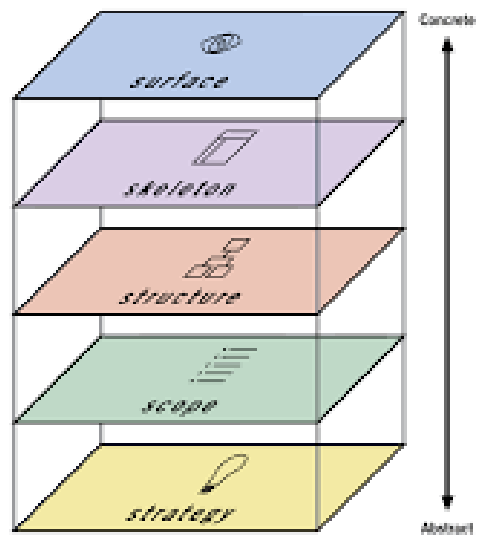

Source: GARRET (2010)

Subsequently, Teixeira, Benedet \& Hoppe (2015) adapted from Garrett (2010) with a combined use of matrices and personas as an alternative way for situations where the customization of the project by public profile, suggesting that the different personas represent stereotyped public profiles and participating in decision-making in the project. To work, it is necessary that each persona be given a weight for the strength of their profile that will be used as a multiplier factor 
in the decision-making process. Teixeira et al. (2018) present a proposed flowchart for design of digital interfaces with a practical example of how to transform design information into function and content requirements (Figure 2). In the aforementioned work, the authors review the literature and propose an approach that assists in the analysis and development of interfaces in a more systematic and visual way. Next, this proposal for an approach materialized in a flowchart that mixes Garrett's (2010) proposal with that proposed by Teixeira, Benedet and Hoppe (2015) is presented.

Figure 2: Flowchart for digital interfaces
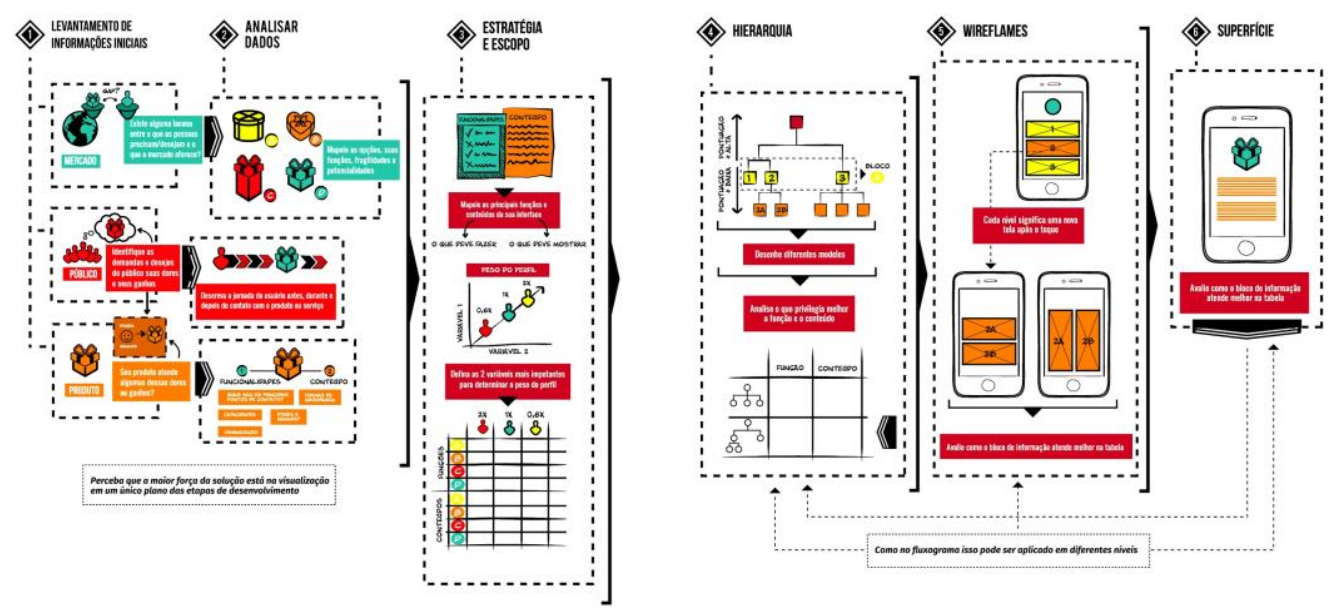

Source: HENRIQUE et al. (2018)

The adaptation made by Teixeira, et al. (2018) proposes that, initially, one should seek information on three fronts essential for the development of any project: the market, the public and the product. After obtaining this information, it is possible to map opportunities, weaknesses and market potential. In the next step, the main functionalities and content of the interface must be defined, and the weights of profiles / personas that will be impacted by the proposed solution calculated. This calculation is essential to advance the 
next steps. In view of the aforementioned definitions, we proceed to the stage, which should establish the hierarchy of the visual interface of the solution. Based on the established hierarchy, it is necessary to structure the wireframe. Finally, in the last step, it is possible to evaluate how different surface alternatives meet the established requirements.

\subsection{Content Design and Sales}

Digital communication has been expanding rapidly, and one of the areas of administrative strategies for this new scenario is content marketing. This, also known as Content Marketing encompasses the "process of planning, creating and sharing content that focuses on the user as a potential customer" (ASSAD, 2016, p. 13). According to Rez (2012), content marketing consists of in an integrated and targeted action, so that the information conveyed to potential consumers understands what the company is, its objectives, the availability of its products and services in order to complete the purchase. Therefore, we see that the purpose is to use the content shared on digital channels in a more personalized way to its users so that they can identify themselves and thus reach the decision to purchase the service or product, in addition to gaining brand authority. One of the ways to structure this analysis can be based on the technique called sales funnel. The Sales Funnel is the set of steps and triggers that aims to support the shopping journey. The definition of each of the stages must be planned in order to deliver the necessary value for the potential client to proceed to the next stage (PEREIRA, 2016).

According to Peçanha (2015), the sales funnel can be considered as a visual model for measuring a user's audience 
journey from their first contact with the company to the end of purchase or after-sale.

Figure 3. Sales funnel.

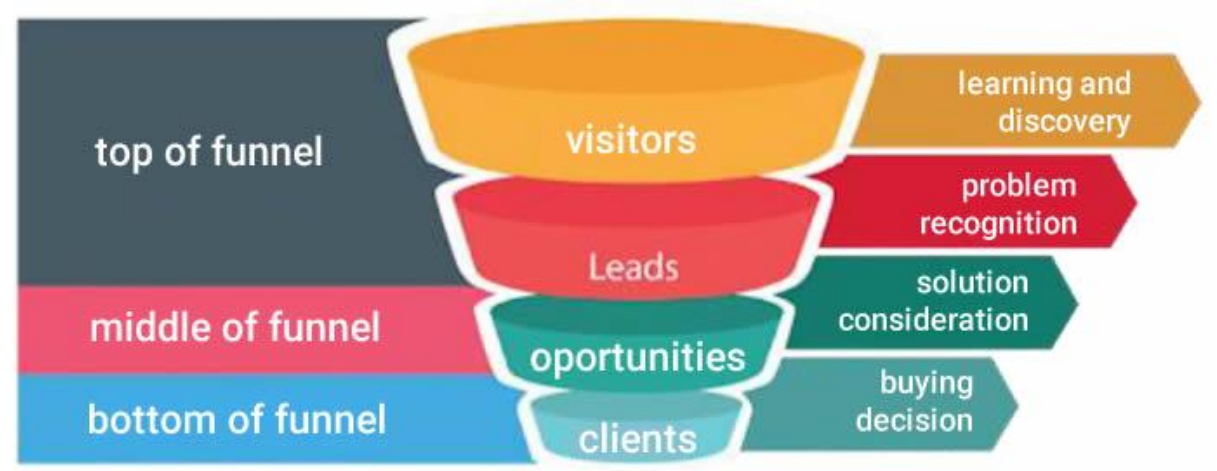

Source: www.atomdigital.com.br

It is divided into 3 stages: top of funnel (stage where the user discovers the need or problem to be solved awakened after a first contact with the company, in this case, with the company's digital interfaces), middle of funnel (stage that the users are in search of solving the perceived needs, however, they do not have a clear solution for this) and bottom funnel (stage in which users are ready to make a decision to purchase). Thus, the content treated in the digital channels of companies can be structured according to each step of the sales funnel in order to attract and convert users to purchase.

\section{METHODOLOGICAL PROCEDURES}

This research is classified as applied, as it aims to generate knowledge of practical application, aimed at solving specific problems (MARCONI; LAKATOS, 2007). Still, it is a case study; it has the purpose of exploring real life situations, describing the situation in the context of its investigation and explaining its possible causal variables (GIL, 2014). The following case study presents the service model used - called LEMMEX - which proposes an adaptation and practical 
application of the Flowchart for digital interfaces, proposed by Teixeira et al. (2018). The practical approach was performed in 4 steps:

1. Diagnosis - this stage was an initial immersion regarding the market, the public served, the products offered and the services related to the company. In this immersion, the main needs, restrictions, opportunities, threats and good practices of the company are identified, focusing on potential users and consumers, as well as the main demands, desires, expectations and interests of the same with the service offered. The profile of the public served was identified through semi-structured interviews and the creation of personas.

2. Analysis - where an examination of the current communication pieces (website and social media) selected to be worked in the consultancy was carried out. This step deepened the information gathered in the previous step through structured analyzes and presented the points of attention and the mapping of opportunities for improvement, weaknesses and potential changes to the interface (website) and engagement (social media). At this moment, it is possible to analyze the journey of the persona (user) to identify how each profile behaves before, during and after having contact with the interface to subsequently improve the content of the pages.

3. Interface plan - in this step, a requirements matrix was applied and a scope was defined from the prioritization of personas and relationship with the content from the perspective of the sales funnel. The analysis matrix serves to evaluate the reaction of each persona with the communication tool in particular and assigns a hierarchical importance of each item within the between those personas and the content.

4. Guidelines - where suggestions were made for improving the usability of the company's website interface 
and adapting content to the media, taking into account the results obtained in the previous steps.

The purpose of this approach, adapted from Teixeira, Henrique, Braglia \& Gonçalves (2018), is to help develop a more rigorous science in diagnosis and design service aimed at a specific audience / persona, organizing a methodology based on strategies for analysis and scope of usability.

\section{RESULTS}

The consultancy described in this case study was hired through a collective project with Sebrae-SC, more specifically through the Inova Sebrae program. The program aimed to offer specialized and customized services for the implementation of new digital solutions or improvements to small businesses. The global project lasted two years and took place between 2018 and 2019. 26 companies from the city of Florianópolis retail area participated in the project. The purpose of the project was to increase the competitiveness and sustainability of small companies in the value chain of the region's digital economy. For this, the work plan provided for a series of actions and solutions such as: lectures, participation in events, international missions, courses, workshops and consultancies for specific areas. Among the consultancies offered to companies, the cases described here are from two companies in the clothing sector and one in the footwear sector. Specifically for this collective project, three consultants from the Lemme group were invited to serve a total of 26 companies in 90 days (in individual consultations of 16 hours each).

In step 1, for the diagnosis of the users' profile, a semistructured interview script and a dynamic spreadsheet were used - completed together with the company representatives, 
via GoogleDrive - where the characteristics of the personas served by the company were defined. At this stage, companies were also asked to provide data regarding their customers' sales so that they could have more basis in defining the personas, thus being able to identify the main forms of payment, products, medium ticket etc. Figure 4 shows the creation script applied in this step.

Figure 4. Semi-structured interview script ${ }^{1}$.

\begin{tabular}{|c|c|c|}
\hline Questions & Guidelines & Example response (M profile) \\
\hline Costumer/Persona & $\begin{array}{l}\text { Name, Age, Profession, } \\
\text { Segment, Subject }\end{array}$ & Married women, mothers, aged 40 to 50 years \\
\hline Representativeness & $\begin{array}{l}\text { Percentage (\%) representing the } \\
\text { customer base or potential } \\
\text { representing the customer base }\end{array}$ & $\begin{array}{l}76 \% \text { (profile with the highest purchase in-store } \\
\text { profile) }\end{array}$ \\
\hline $\begin{array}{l}\text { Reason for the } \\
\text { interest }\end{array}$ & $\begin{array}{l}\text { Why is the client interested in } \\
\text { this cause / purpose? }\end{array}$ & $\begin{array}{l}\text { For offering good products and the store's tradition } \\
\text { in the city }\end{array}$ \\
\hline Channels & $\begin{array}{l}\text { In descending order of } \\
\text { importance }\end{array}$ & Instagram, Facebook, WhatsApp, E-mail \\
\hline \multirow{4}{*}{$\begin{array}{l}\text { Language type / } \\
\text { message shape }\end{array}$} & Pessoal ou Institucional & Personal or Institutional \\
\hline & Direct or indirect & Direct (focus on reason of interest) \\
\hline & Informal or Formal & Formal (without excess of formality) \\
\hline & Technician or generalist & $\begin{array}{l}\text { Generalist (broader and managerial view; not } \\
\text { technical and specific) }\end{array}$ \\
\hline \multirow[t]{2}{*}{ Revenue models } & Ex. Credit Card & plots \\
\hline & Ex. In Cash & - \\
\hline
\end{tabular}




\begin{tabular}{l|l|l} 
& Ex. Crerdit & plots \\
\hline Type of approach & Specials & - \\
\cline { 2 - 3 } & Relationship & Solutions (family products) \\
\cline { 2 - 3 } & Results & Result (examples / cases from other clients) \\
\hline What frustrates? & $\begin{array}{l}\text { What stops you from believing } \\
\text { in the product / service? }\end{array}$ & $\begin{array}{l}\text { inflexible payment terms, lack of product } \\
\text { information, lack of products in the store, aesthetics } \\
\text { and comfort }\end{array}$ \\
\hline Main pains & $\begin{array}{l}\text { Which pains can we treat and } \\
\text { which ones should we not } \\
\text { intensify }\end{array}$ & $\begin{array}{l}\text { digital communication (contact and content } \\
\text { strategy) }\end{array}$ \\
\hline
\end{tabular}

Source: Research data.

With the dynamic spreadsheet filled out and the persona characteristics defined, a matrix was used - shared and also filled in with company representatives - to define the profile weight in relation to the business. The weights varied from 1 (one) for "little (a)" to 5 (five) for "much (a)", distributed in two variables: "Purchasing power, decision or influence" and "Representativeness". The attribution of grades for each variable was determined by the managers and with the guidance of the consultants. The result of the weight of the profiles was defined by the average of the marks attributed in both variables, as shown in figure 5 . 
Figure 5. Calculation of profile weight

\begin{tabular}{r|r|r|r} 
Profile & $\begin{array}{r}\text { Purchasing power, } \\
\text { decision or influence }\end{array}$ & Representativeness & Peso \\
\hline Mother (M) & 3 & 5 & 4 \\
\hline Man (H) & 3 & 3 & 2,5 \\
\hline Young Woman (YW) & 3 & 3 & 2,5 \\
\hline
\end{tabular}

Source: Research data.

Weights 4,5, 2,5 and 2,5 comprised the "main business audience" profile and represented $50.1 \%$ to more than $75 \%$ of the user base, as shown in figure 6 .

Figure 6: Profile weight and importance to the business

\section{PERSONA/PÚBLICO - PESO DO PERFIL}

\begin{tabular}{|c|c|}
\hline & $\begin{array}{l}\text { Indique abaixo com a } \\
\text { foto/ínicial do nome onde } \\
\text { está cada persona }\end{array}$ \\
\hline & A \\
\hline 氖氮 & 4 \\
\hline 풌 뭉 & $\mathrm{J}$ \\
\hline$\underset{\tilde{\Sigma}}{\underline{\Psi}}$ & 2 \\
\hline & \begin{tabular}{l|lllll}
0 & 1 & 2 & 3 & 4 & 5
\end{tabular} \\
\hline & $\begin{array}{l}\text { \% PERCENTUAL DA } \\
\text { RECEITA }\end{array}$ \\
\hline $\begin{array}{l}\text { Analise o poder de decisäo da persona segundo } \\
\text { os critérios abaixo: }\end{array}$ & $\begin{array}{l}\text { Ver representatividade da } \\
\text { persona na base: Flchas } \\
\text { de Persona }\end{array}$ \\
\hline $1=1 x$ ano, $e /$ ou até $X X$ reais & $1=0$ à $15 \%$ da receita \\
\hline $2=2 x$ ano, e/ou até $X X$ reais & $2=15,1$ à $30 \%$ da receita \\
\hline $3=3 \mathrm{X}$ ano, e/ou até $X X$ reais & $3=30,1$ à $50 \%$ da receita \\
\hline $4=4 x$ ano, e/ou até $X X$ reais & $4=50,1 \%$ à $75 \%$ dareceita \\
\hline $5=5 X$ ano, e/ou até $X X$ reais & $5=$ mais de $75 \%$ da receita \\
\hline & $\begin{array}{l}\text { Caso uma das personas } \\
\text { seja } 5 \text { nesta variavel, alerte } \\
\text { o cliente que ele está } \\
\text { vunerável e precisa } \\
\text { diversificar seu público }\end{array}$ \\
\hline
\end{tabular}

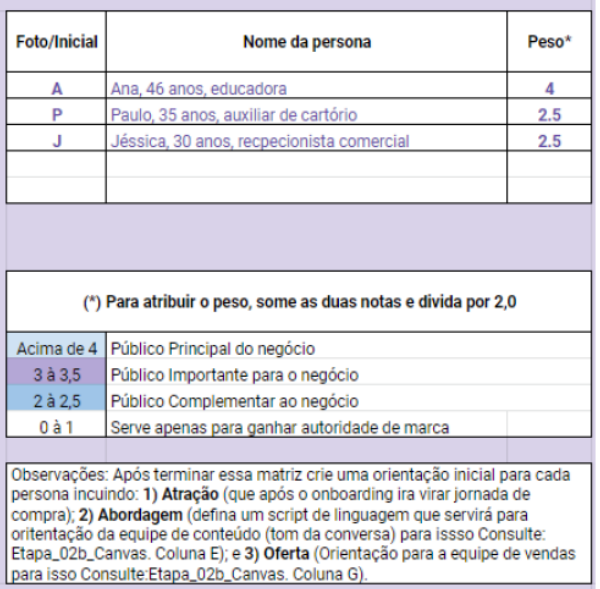

Source: Research data.

With the data obtained in the structured interview and the data from the matrix to define the relevance of each profile for the business, the details of the personas were created, as shown in figures 7 and 8. 
Figure 7. Mother persona profile (M)

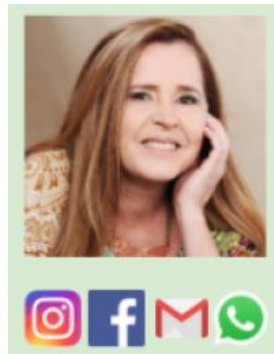

Nome: Ana Cândida Idade: 46 anos Prade: Rio do Sul
Ana é mãe, esposa, filha, cunhada e tia. Cuida da casa, da familia e ainda trabalha: é educadora. Gosta de sua casa arrumada e organizada. É dedicada a seus filhos e ao seu marido, sempre fazendo o máximo possivel para antever suas necessidades e atendê-las.

Nascida e criada na cidade de Rio do Sul, valoriza a sua cidade e seu povo. É religiosa, acredita que sua força vêm de sua fé, a qual procura passar como valores a seus filhos e familiares.

\section{0 que precisa:}

0 quê frustra:

De um tênis confortável com design urbano - Ausência de condições de pagamento mais flexivel; casual para usar no seu dia a dia de inverno, - Desconhecimento das especificações dos produtos nos mais variados ambientes que envolvem pelos atendentes;

sua rotina: escola, supermercado, farmácia, - Calçados confortáveis, no entanto, feios e grosseiros, sua rotina. escola, supermercado, farmacia, para seus filhos em idade escolar
- Calçados confortáveis, no enta

Source: Research data

Figure 8. Detail of the profile of the Mother persona (M)

Diagnóstico

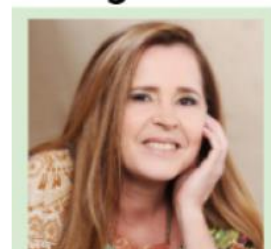

(0) $F M O$

Nome: Ana Cândida

Idade: 46 anos

Idade: 46 anos

Profissão: Educadora
Ana Cândida, 46 | Calçados para ela e sua família

\section{Produtos comprados pela Ana:}

Tenis casual cinza

- Comfortflex tamanco

Ticket médio : R\$ 133,30

Ticket Médio da Schmidt: RS 124,51;

As compras no valor de 133,30 estẫo em $2^{\circ}$ lugar em indice de de recorrencias. Plumax vans -49 ocorrências (produto mais vendido) cor única: 37 ocorrências $\left(5^{\circ}\right.$ mais vendido); Comfortflex tamanco - 16 ocorrências;

Mulheres representam $76,62 \%$ das compras no crediáric

Canais:

Conheceu a Schmidt Calçados pela sua tradição e referência na cidade de Rio do Sul. Passou a segui perfil da loja no Facebook, onde acompanha as promoçôes. Depois, passou a acompanhar a loja pelo destaque.
Em qual linguagem deve ser tratado:

A linguagem é informal e amigável, no entanto direta e técnica, sem rodeios para esclarecer sobre as qua lidades edurablidade dos produros. Acliente deve se sentir confortavel para perguntar e tirar duvidas, que nẫo deve tentar empurrar produtos que não estejam de acordo com as necessidades apresentadas pela cliente.

Source: Research data

The assembled profiles are used to analyze the user's journey and how each profile behaves before, during and after contact with digital interfaces. Based on this idea, in step 2, a qualitative analysis was carried out regarding the user's perception while social media from of the sales funnel logic (top, middle and bottom of the funnel) considering the main approach of each stage of the funnel.

Step 2 mixes with step 3 for already presenting the results of the analysis and pointing out directions on how to work on the content with a view to greater engagement and sales. In step 3, it analyzed what was already done in digital media for each stage of the funnel, so first it was observed 
how the content behaved in relation to learning and discovery, identifying the positive points and indicating possible improvements as shown in figure 8.
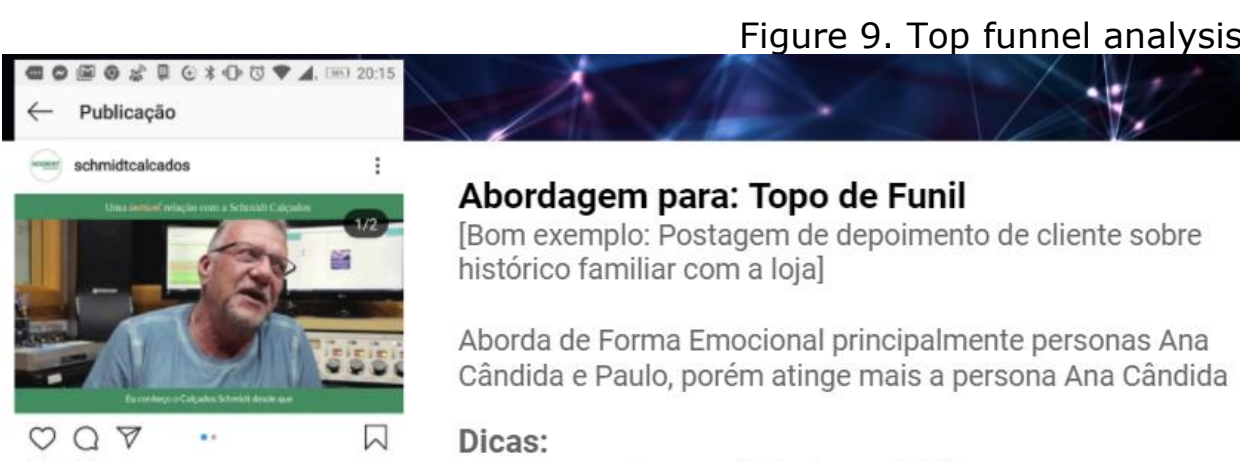

20 curtidas

schmiltcalcados 0 nosso querido amigo e cliente Otavio Kaufamann, tem uma história muito bonita com a @Schmidtcalçados, além de várias lembranças de farmilia que ele viveu por aqui. Confir com a gente esse depoimentol I. \#depoimento

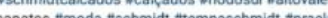
sapatos \#ñeies

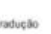

\section{Abordagem para: Topo de Funil}

[Bom exemplo: Postagem de depoimento de cliente sobre histórico familiar com a loja]

Aborda de Forma Emocional principalmente personas Ana Cândida e Paulo, porém atinge mais a persona Ana Cândida

Dicas:

- Apresentou propósito [com afeto]

Humanizou a relação [fato real]

Deu protagonismo ao cliente;

Lembrar que, em Topo de Funil:

+ Vida real |- Abordagem comercial.

ก $\quad \mathrm{a} \oplus 0$ ○

Source: Research data

The focus of the funnel analysis was to analyze the content in what would be the recognition of the problem or consideration of the solution that the user could consider when accessing the social media of the store as shown in Figure 9.

Figure 10. Middle Funnel analysis

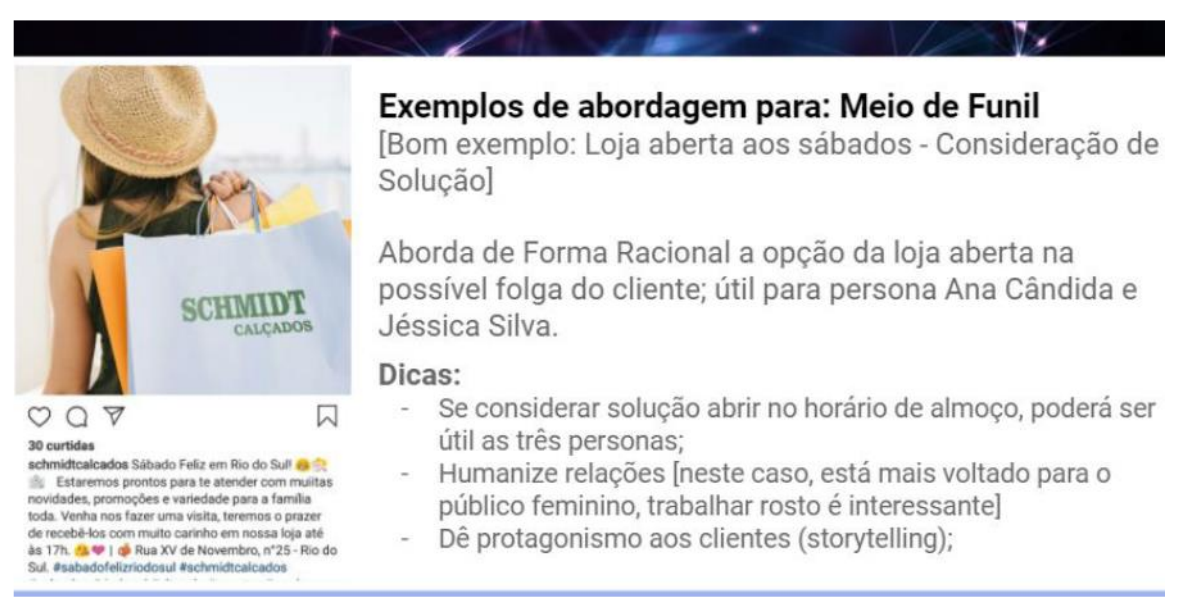

Source: Research data

As for the funnel fund phase, the purchase opportunities 
for the user were analyzed, considering the intention and evaluation, as shown in the following image ${ }^{2}$ :

Figure 11. Funnel bottom analysis

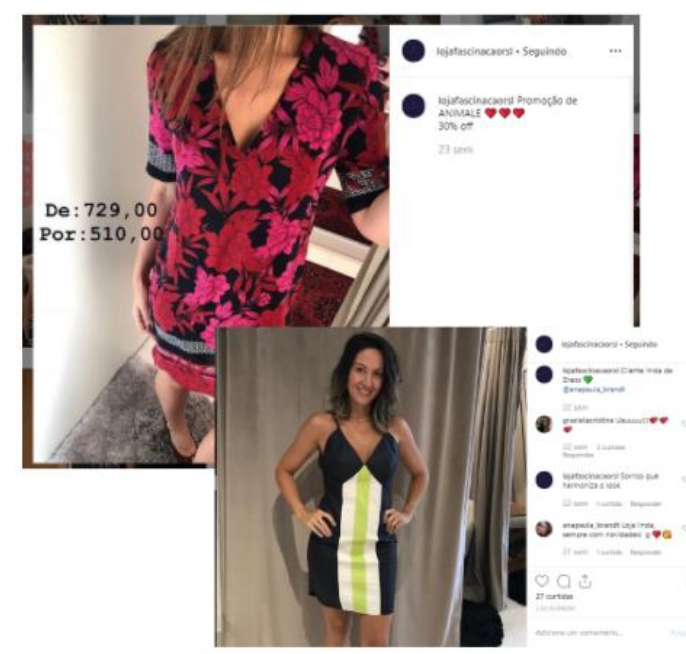

\section{[Oportunidades]}

Ex. de abordagens para o fundo de funil

[Destaques]

Post Promoção Animale: mostrou a queda do preço.

Vídeos no stories com informação do produto.

Post cliente real: gerou comentários positivos, demonstra naturalidade e a foto sem tratamento de imagem mostra originalidade e personalidade.

Source: Research data

In view of the whole journey observed, step 4 was followed, where the user objection directions were pointed out as much as the emotional and rational aspect for each persona, that is, which communication strategy can be treated with each determined user profile to break the rational obstacles and emotional issues that prevent you from finalizing your purchase.

Figure 12. Persona vs. Objections

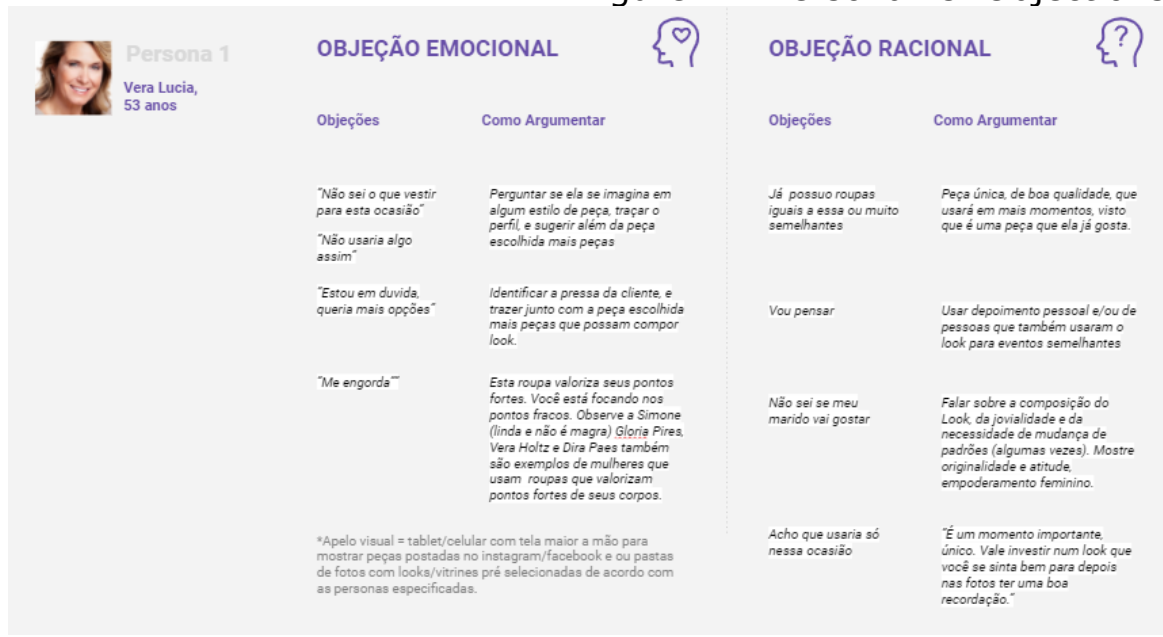

Source: Research data 
Finally, all data, results and guidelines were presented to the representatives of the stores included in the project (that is, the managers and owners of the business to which the consultancy was provided) for the adoption of the best practices.

\section{FINAL CONSIDERATIONS}

The method employed allowed the optimization of the analysis time (considering the workload that had to develop the work), greater depth in the relevant items for the solution proposal and more security for decision making (by focusing on data for the construction of personas profiles, as well as having its content analysis - aired on the digital communication channels of the company for which the consultancy was carried out - with the specific objective of converting its users to sales, thus approaching their real needs for the relationship between the company and Thus, taking into account the characteristics of an agile, usercentered approach.

\section{End Notes}

1 It is important to note that the original table had three (3) user profiles (this for each of the companies), where each profile received the same treatment as the semi-structured questionnaire presented here and analysis of the data sheet referring to customers and sales. Only the profile Mother (M) is reported in this table, as an example of the application.

2 The examples placed in the images vary between the three stores where consultancies were carried out. 


\section{REFERENCES}

DAWSON, R., \& DAWSON, C. Practical proposals for managing uncertainty and risk in project planning. International Journal of Project Management, n.16, v.5, p.299-310,1998.

DEWEY, J. Arte como experiência. São Paulo: Martins Fontes, 2010.

GARRET, J. J. The elements of User Experience: user-centered design for the web and beyhond. New Riders Press, 2010.

GIL, A. C. Métodos e técnicas de pesquisa social. São Paulo: Atlas, 2015.

COCKBURN, A. Agile software development. Addison-Wesley, Boston, 2002.

HIGHSMITH, J., \& COCKBURN, A. Agile software development: The business of innovation. Computer, n.34, v.9, p.120-127, 2001.

HIGHSMITH, J. R. Agile project management: creating innovative products. Pearson Education, 2009.

KOTLER, P., KARTAJAYA, H., SETIWAN, I. Marketing 4.0: do tradicional ao digital. Rio de Janeiro: Sextante, 2017.

MARCONI, M. A. \& LAKATOS, E. M. Metodologia científica: ciência e conhecimento científico, métodos científicos, teoria, hipóteses e variáveis. 5. ed. São Paulo: Atlas, 2007.

NIELSEN, J. \& LORANGER, H. Usabilidade na Web: projetando websites com usabilidade. Rio de Janeiro: Elsevier, 2007.

NORMAN, D. \& DRAPER, S. W. User centered system design: New Perspectives on Human-Computer Interaction. New Jersey: Lawrence Erlbaum Associates. 1986

NORMAN, D. Emotional Design: why we love (or hate) everyday things. NY: Basic Books, 2004.

NORMAN, D. O design do dia-a-dia. Rio de Janeiro: Rocco, 2006.

PEÇANHA, V. Marketing Digital: O que é isso, afinal? Brasil,2015. Disponível em http://marketingdeconteudo.com/marketingdigital/. Acesso em: 21/9/2015.

PERMINOVA, O., GUSTAFSSON, M. \& WIKSTRÖM, K. Defining uncertainty in projects: a new perspective. International Journal of Project Management, v, 26, n.1, p. 73-79, 2008.

PEREIRA, $V$. O que é e para que serve o funil de vendas? Resultados Digitais, 2016.2 Disponível em: https://resultadosdigitais.com.br/blog/o-que-funil-de-vendas/.

Acesso em: 23 de dezembro de 2020.

STEFFENS, W., MARTINSUO, M. \& ARTTO, K. Change decisions in product development projects. International Journal of Project Management, v. 25, n. 7, p. 702-713, 2007.

REZ, R. O que é Marketing de Conteúdo: Como usar o conteúdo 
a favor da suamarca. Marketing de Conteúdo. [Internet]. Disponível em: http://www.Marketingdeconteudo.com.br/Marketing-deconteudo/o-que-e-Marketingde-conteudo-como-usar-o-conteudoa-favor-da-sua-marca/. 2017.

TEIXEIRA, J. M., BENEDET, G. B., \& HOPPE, A. Um passo-a-passo para transformar pesquisa informacional $e$ personas em requisitos de projeto. E-revista logo. Florianópolis, pp. 1-16, 2015. Disponível em: http://incubadora.periodicos.ufsc.br/index.php/eRevistaLOGO/artic le/view/3705/4386. Acesso em 10 julho 2020.

TEIXEIRA, Júlio M.; HENRIQUE, Caroline D.; BRAGLIA, Israel A.; GONÇALVES, Berenice S.; "Proposta de fluxograma para design de interfaces digitais: um exemplo prático de como transformar informações de projeto em requisitos de função e conteúdo", p. 2567-2581. In: Anais do $13^{\circ}$ Congresso Pesquisa e Desenvolvimento em Design(2018). São Paulo: Blucher, 2019.Disponível em: https://www.proceedings.blucher.com.br/article-details/propostade-fluxograma-para-design-de-interfaces-digitais-um-exemploprtico-de-como-transformar-informaes-de-projeto-em-requisitosde-funo-e-contedo-30132. Acesso em 10 julho 2020. 